\title{
Potential of endophytic fungi as biocontrol agents of Duponchelia fovealis (Zeller) (Lepidoptera:Crambidae)
}

\author{
R. F. Amatuzzi *, N. Cardoso ${ }^{b}$, A. S. Poltronieri ${ }^{a}$, C. G. Poitevin ${ }^{a}$, P. Dalzoto ${ }^{a}$, \\ M. A. Zawadeneak ${ }^{a}$ and I. C. Pimentel ${ }^{a}$ \\ ${ }^{a}$ Departamento de Patologia Básica, Setor de Ciências Biológicas, Universidade Federal do Paraná - UFPR, \\ Avenida Coronel Francisco H. dos Santos, 100, CP 19031, CEP 81531-980, Curitiba, PR, Brazil \\ ${ }^{b}$ Departamento de Matemática e Estatistica, Universidade Federal de Rondônia - UNIR, \\ Rua Rio Amazonas, 351, Jardins dos Migrantes, CEP 76900-726, Ji-Paraná, RO, Brazil \\ *e-mail: rfamatuzzi@gmail.com
}

Received: July 15, 2016 - Accepted: March 22, 2017 - Distributed: October 31, 2018

(With 1 figure)

\begin{abstract}
This study reports the first assessment of endophytic fungi isolated from strawberry leaves and selection of isolates for the control of Duponchelia fovealis, a new pest of strawberries. A total of 400 strawberry leaves of the cultivar 'Albion' were collected in four commercial farms. Leaves were disinfected, cut in fragments, and placed on Petri dishes containing potato dextrose agar media with tetracycline and incubated for 30 days. Following this time, 517 fungal colonies were isolated, and thirteen genera were identified: Cladosporium, Aspergillus, Nigrospora, Fusarium, Trichoderma, Chaetomium, Alternaria, Paecilomyces, Penicillium, Ulocladium, Bipolaris, Diaporthe, and Phoma. Eight isolates belonging to the genera Aspergillus, Diaporthe, Paecilomyces, and Cladosporium were selected for pathogenicity bioassays against third instar larvae of $D$. fovealis. Isolates of Paecilomyces induced the highest mortality rates.
\end{abstract}

Keywords: Fragaria x ananassa, European Pepper Moth, microbial control, entomopathogenic fungi.

\section{Fungos endofíticos para o biocontrole de Duponchelia fovealis (Zeller) (Lepidoptera: Crambidae)}

\begin{abstract}
Resumo
Este trabalho apresenta a primeira contribuição no isolamento de fungos endofíticos de folhas de morangueiro e na seleção de isolados para controle de Duponchelia fovealis, uma nova praga do morangueiro. Foram coletadas 400 folhas da cultivar 'Albion' em quatro lavouras comerciais de morangueiro. As folhas foram desinfetadas, cortadas em fragmentos e depositadas em placas de Petri contendo Ágar Batata Dextrose como meio, em conjunto com tetraciclina e incubados durante 30 dias. Um total de 517 colônias fúngicas e treze gêneros foram isolados: Cladosporium, Aspergillus, Nigrospora, Fusarium, Trichoderma, Chaetomium, Alternaria, Paecilomyces, Penicillium, Ulocladium, Bipolaris, Diaporthe e Phoma. Oito isolados pertencentes aos gêneros Aspergillus, Diaporthe, Paecilomyces e Cladosporium foram selecionados para os bioensaios de virulência contra larvas de $3^{\circ}$ instar de D. fovealis. Isolados de Paecilomyces causaram as maiores taxas de mortalidade.
\end{abstract}

Palavras-chave: Fragaria x ananassa, European Pepper Moth, controle microbiano, fungos entomopatogênicos.

\section{Introduction}

The European pepper moth, Duponchelia fovealis (Zeller, 1847), (Lepidoptera: Crambidae) is native to marshlands of southern Europe and the eastern Mediterranean region (CABI, 2016). This moth is a greenhouse pest of cut flowers, vegetables, and aquatic plants in northern Europe and Canada (CABI, 2016). It has also become a pest of strawberries grown commercially in Europe (Bonsignore and Vacante, 2009; Franco and Baptista, 2010; Efil et al., 2014) and South America (Zawadneak et al., 2016). Because this is an exotic species, arthropod natural enemies are absent or insufficiently effective to control it (CABI, 2016; Zawadneak et al., 2015a). In addition, chemical control may not be as effective as larvae inside stems are protected from treatment (CABI, 2016), requiring several applications. Since strawberries are mostly grown in greenhouses, the control based only on chemical pesticides would result in residues on fruits and impact on the environment (Bernardi et al., 2015). In these cases, microorganisms could be a sustainable alternative control method (Gonzalez et al., 2016) with benefits for 
consumers, farmers, and the environment (Bonsignore and Vacante, 2009; Lacey et al., 2015; Gonzalez et al., 2016). For these reasons, biological control based on microorganisms represents a complementary strategy for further development (Zawadneak et al., 2015a; Gonzalez et al., 2016); however, studies on this type of approach involving $D$. fovealis are nonexistent.

Fungi have several characteristics that make them suitable as biological control agents, as they can directly penetrate through the insect cuticle, and increase the potential for epizootics and mortality rates in the pest population (Hajek and Delalibera, 2010; Gonzalez et al., 2016). These fungi can colonize plant tissues as endophytes (Arnold, 2007), apparently remaining assymptomatic (Urrutia et al., 2002; Arnold and Lutzoni, 2007; Vega et al., 2009). Endophytes can have beneficial effects on host plants, e.g., promoting plant growth, reducing disease severity, inducing plant defense mechanisms, and producing anti-herbivore products (Arnold et al., 2003; Arnold and Lewis, 2005; Schulz and Boyle, 2005; Rudgers et al., 2007). These fungi have been detected in hundreds of plant species (Urrutia et al., 2002; Gonzalez et al., 2016).

Endophytic fungi of the genera Acremonium, Beauveria, Cladosporium, Clonostachys, Paecilomyces, Lecanicillium, Verticillium, and Isaria have been isolated from several cash crops species, such as coffee (Coffea Arabica L.), potato (Solanum tuberosum L.), corn (Zea mays L.), cotton (Gossypium hirsutum L.), tomato (Lycopersicon esculentum Mill.), banana (Musa paradisiaca L.), date palm (Phoenix dactylifera L.), rice (Oryza sativa L.), cocoa (Theobroma cacao L.), lettuce (Lactuca sativa L.). and bean (Phaseolus vulgaris L.) (Jones, 1994; Leckie, 2002; Ownley et al., 2004; Posada and Vega, 2005; Quesada-Moraga et al., 2006; Akello et al., 2007; Zawadneak et al., 2015b; Parsa et al., 2016).

This study was aimed at identifying endophytic fungi present in strawberry leaves and select isolates for the control of Duponchelia fovealis, a new pest of this crop.

\section{Material and Methods}

\subsection{Samples}

Strawberry leaves were collected from four commercial farms in the state of Paraná, Brazil (Table 1), in March 2012, totaling 100 leaves randomly collected per area. Samples were taken to the laboratory in plastic bags and processed on the same day.

\subsection{Isolation of endophytic fungi}

Leaves were first washed in water to remove dust and dirt residues and then immersed in $70 \%$ ethanol for 30 seconds and $1 \%$ sodium hypochlorite solution for 3 minutes.
The material were then thoroughly rinsed twice in sterile distilled water. After this process, four foliar pieces $(2 \times 2 \mathrm{~cm})$ were placed in separate Petri dishes $(90 \times 15 \mathrm{~mm})$ containing potato dextrose agar (PDA) with tetracycline $(100 \mu \mathrm{L} / \mathrm{ml})$. The adaxial part of the leaf was turned upward. Plates were incubated in a BOD chamber at $28 \pm 0.5^{\circ} \mathrm{C}$ for 30 days. Fungi grown from leaves were transferred to Petri dishes containing PDA media.

The frequency of isolation $(\mathrm{FI}=$ number of leaf fragments with fungus growth/ total number leaf fragments) was calculated (Azevedo, 1998).

To compare the frequency of isolation among farms, the data were transformed $(\log \mathrm{x}+1)$ to normalize the distributions and analyzed with the ANOVA F test and the Tukey test $(\mathrm{p}<0.05)$ using the software Assistat 7.7.

\subsection{Morphological characterization}

The morphological identification of endophytic fungi was based on macro and micromorphology (Kern and Blevins, 1999). Monosporic colonies were cultivated in Sabouraud media and incubated for 14 days at $28 \pm 0.5^{\circ} \mathrm{C}$. Non-sporulated isolates were classified as Mycelia sterilia. Isolates were maintained at the CMRP (Microbiological Collections of the Parana Network - TAXON line).

\subsection{Molecular characterization}

\subsubsection{DNA isolation and PCR amplification}

DNA extraction was carried out according to Badali et al. (2009)

The PCR reaction amplified the regions ITS1-5,8S-ITS2 of ribosomal DNA, partial $\beta$-tubulin gene, and partial calmodulin gene with the following pairs of primers: ITS1 5'TCCGTAGGTGAACCTGCGG3' and ITS4 5'TCCTCCGCTTATTGATATGC3' (White et al., 1990), Bt2a 5'GGTAACCAAATCGGTGCTGCTTTC3' and Bt2b 5'ACCCTCAGTGTAGTGACCCTTGGC3' (Glass and Donaldson, 1995), andCL1 5'GARTWCAAGGAGGCCTTCTC3', and CL2A 5'TTTTGCATCATGAGTTGGAC3' (Mulè et al., 2004), respectively.

\subsubsection{DNA sequencing}

DNA sequencing was performed with $1-3 \mu \mathrm{L}$ of the purified PCR product, $0.5 \mu \mathrm{L}$ of buffer, $0.5 \mu \mathrm{L}$ of each primer, $0.5 \mu \mathrm{L}$ of BigDye $^{\circledR}$, and ultra-pure water, making up a final volume of $10 \mu \mathrm{L}$. Amplification conditions were: $96{ }^{\circ} \mathrm{C}$ for $1 \mathrm{~min}$, and 35 cycles at $96^{\circ} \mathrm{C}$ for $10 \mathrm{~s}, 50{ }^{\circ} \mathrm{C}$ for $5 \mathrm{~s}$ and $60^{\circ} \mathrm{C}$ for 4 minutes. Sequencing was carried out with a DNA Sequencer Auto Applied BioSystem 3500.

The sequences obtained were aligned and edited with the package Staden Package version 1.6 and the software MEGA version 4.0. Subsequently they were compared

Table 1. Location of the sampling areas of strawberry leaves.

\begin{tabular}{cccc}
\hline Site & Location & Geographical Coordinates & Crop \\
\hline A & São José dos Pinhais & $25^{\circ} 36^{\prime} 753^{\prime}$ S and $49^{\circ} 04^{\prime} 887^{\prime}$ W & Organic \\
B & Pinhais & $25^{\circ} 23^{\prime} 30^{\prime}$ S and $49^{\circ} 07^{\prime} 30^{\prime}$ W & Organic \\
C & São José dos Pinhais & $25^{\circ} 33^{\prime} 580^{\prime}$ S and $49^{\circ} 08^{\prime} 887^{\prime} \mathrm{W}$ & Conventional \\
D & São José dos Pinhais & $25^{\circ} 35^{\prime} 820^{\prime}$ S and $49^{\circ} 05^{\prime} 866^{\prime} \mathrm{W}$ & Conventional \\
\hline
\end{tabular}


with other sequences from the NCBI database with the software BLAST.

\subsection{Insects}

Larvae used in the experiments were obtained from the rearing facility at the Professor Angelo Moreira da Costa Lima Laboratory of Entomology/ UFPR, fed an artificial diet and kept at $70 \pm 10 \% \mathrm{RH}, 25 \pm 2{ }^{\circ} \mathrm{C}$, and 14-h photoperiod (Zawadneak et al., 2017).

\subsection{Isolated fungi}

The endophytic fungi used in the pathogenicity tests were CD72E1 - Aspergillus terreus, G13 Diapothe endophytica, G28-Cladosporium cladosporides, G41-Paecilomyces lilacinus, G42- Paecilomyces lilacinus, G70-Aspergillus sydowwi, OB96E2- Cladosporium sphaerospermum, and CD34F1- Fusarium solani.

\subsection{Fungal preparations}

In order to mass produce conidia, isolates were inoculated on malt and incubated at $28 \pm 1{ }^{\circ} \mathrm{C}$ for 14 days in the dark. Colonies were then scraped and added to $100 \mathrm{~mL}$ of sterilized distilled water and Tween $80^{\circledR}(0.001 \%)$. The suspension was agitated for ten minutes at room temperature on an orbital shaking incubator at $150 \mathrm{rpm}$, and filtered through a sterilized cheesecloth. Conidia concentration was determined using a hemocytometer and adjusted to a final concentration of $1 \times 10^{9}$ conidia $/ \mathrm{mL}$. Conidial viability was assessed before the suspension preparation, and germination rates were higher than $95 \%$ in 24 hours at $28 \pm 0.5^{\circ} \mathrm{C}$.

\subsection{Pathogenicity bioassay}

Eight endophytic fungi were evaluated in bioassays against $D$. fovealis.

Artificial diet was place in twenty-four well culture plates. $D$. fovealis larvae were transferred individually to the wells with the aid of a fine tip brush (\#2). This assay consisted of three replicates per treatment and a negative control, totaling 96 larvae per treatment.

In the plate containing 24 larvae, $1 \mathrm{~mL}$ of conidial suspension at the concentration of $1 \times 10^{9}$ conidia $/ \mathrm{mL}$ was sprayed with a SAGYMA ${ }^{\circledR}$ Airbrush. A $1 \mathrm{~mL}$ solution of $0.1 \%$ Tween 80 was used as control. Plates were incubated at $25 \pm 1{ }^{\circ} \mathrm{C}, 14$-h photoperiod, and $60 \pm 10 \% \mathrm{RH}$ for eight days.

Mortality criteria were based on insect's response to touch, color, and texture. Dead larvae were placed in Petri dishes with moistened sterile cotton for emergence of fungi from the host. The experimental design was completely randomized.

Fungal efficacy was based on means and mortality data (\%) (Abbott, 1925) and compared with the ANOVAF test and the Tukey test $(\mathrm{p}<0.05)$ with softwares GraphPad Prism 5.03 and Assistat 7.7.

\subsection{Estimation of the mean lethal concentration (LC50)}

In this second phase of the mortality bioassay, five concentrations were tested $1.0 \times 10^{3}, 1.0 \times 10^{4} ; 1.0 \times 10^{5}$; $1.0 \times 10^{6} ; 1.0 \times 10^{7}$ and $1.0 \times 10^{8}$ conidia $/ \mathrm{mL}$ of the isolates that induced the highest mortality rates in the pathogenicity bioassay.

The procedures were the same as those used in the first phase, consisted of $D$. fovealis larvae in twenty-four well culture plates sprayed with a conidial suspension at a given concentration, with five replicates per treatment. Mortality was assessed using the same criteria described previously.

The experimental design was completely randomized and the results were compared with the Probit analsyis) with Polo-PC - Leora Software, 1987.

\section{Results}

\subsection{Prevalence of isolates}

A total of 1600 foliar fragments were collected from the four areas and 517 endophytic colonies were isolated. The prevalence of isolates was 32\% (Table 2), varying among the areas evaluated, with values ranging from low to average prevalence $(24.3-45.8 \%)$. Area A showed the highest number of isolates (183), followed by area B with 123 isolates, while areas C and D had 114 and 97 (F: 13.2939, df: 3; 396; $\mathrm{p}<0.05$ ) isolates, respectively.

\subsection{Composition of the endophytic assemblages}

The 278 endophytic fungi isolated in this study were categorized into 15 taxa (Table 3 ) based on morphological characteristics, but 239 non-sporulating fungi could not be identified.

The genera Aspergillus spp., Paecilomyces spp., Alternaria spp., Penicillium spp. and Cladosporium spp. were separated into two or more morphospecies based on the size of the colony and conidial characteristics. As shown in Figure 1, Cladosporium sp. had the highest frequency of isolates. Alternaria sp. was the second most frequent endophytic taxon followed by Diaporthe sp., with frequencies of 19,12 , and $9.31 \%$ respectively.

The fungi used in the tests against $D$. fovealis caterpillars were identified by molecular analysis as: Aspergillus terreus (CD72E1), Aspergillus sydowwi (G70), Paecilomyces lilacinus (G41; G42), Cladosporium sphaerospermum (OB96E2), Cladosporium cladosporides (G28), Diaporthe endophytica (G13), and Fusarium solani (CD34F1). Sequencing of

Table 2. Prevalence of isolates and number of taxa of fungal endophytes isolated from strawberry leaves at each site.

\begin{tabular}{lcccc}
\hline \multicolumn{1}{c}{ Characteristic } & Site A & Site B & Site C & Site D \\
\hline N $^{\circ}$ of samples & 100 & 100 & 100 & 100 \\
N $^{\circ}$ of isolates & $183 * \mathrm{a}$ & $123 * \mathrm{~b}$ & $114 * \mathrm{~b}$ & $97 * \mathrm{~b}$ \\
average deviation & 1.146 & 0.941 & 0.829 & 0.926 \\
Isolate prevalence & $45.8 \%$ & $30.7 \%$ & $28.5 \%$ & $24.3 \%$ \\
$(\%) * *$ & & & &
\end{tabular}

* Comparison of means using the Tukey test at 0.05 probability. Same lowercase letters do not differ at $95 \%$ level; ** Isolate prevalence $(\%)=($ total number of leaf pieces yielding more than one isolate)/(total number of leaf pieces in that trial) $\mathrm{x} 100$. 


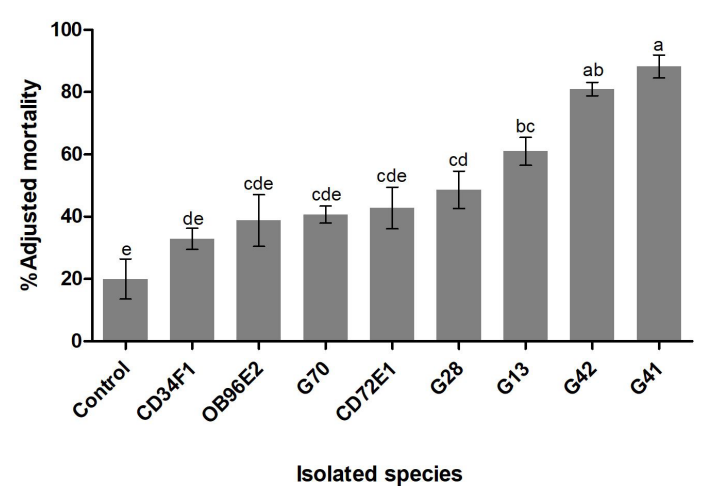

Figure 1. Adjusted mortality percentage induced by conidia suspension and distilled water (control). Tukey test was significant at $1 \%(\mathrm{~F} 23.64=d f=8) . \mathrm{CD} 34 \mathrm{~F} 1=$ Fusarium solani; OB96E2 = Cladosporium sphaerospermum; $\mathrm{G} 70=$ Aspergillus sydowwi CD72E1 = Aspergillus terreus; $\mathrm{G} 28$ = Cladosporium cladosporides; G13 = Diaporthe endophytica; $\mathrm{G} 42=$ Paecilomyces lilacinus; $\mathrm{G} 41$ = Paecilomyces lilacinus.

Table 3. Prevalence of endophytic fungal genus isolated from strawberry leaves.

\begin{tabular}{ccc}
\hline Genera & Number of isolates & $\mathbf{\%}$ \\
\hline Trichoderma sp. & 2 & 0.7 \\
Fusarium spp. & 2 & 0.7 \\
Paecilomyces spp. & 4 & 1.43 \\
Nigrospora sp. & 11 & 3.95 \\
Ulocladium sp. & 15 & 5.39 \\
Diaporthe sp. & 16 & 5.75 \\
Phyllosticta sp. & 16 & 5.75 \\
Bipolaris sp. & 17 & 6.11 \\
Phoma sp. & 18 & 6.47 \\
Chaetomium sp. & 18 & 6.47 \\
Penicillium sp. & 21 & 7.55 \\
Mycelia sterilia & 24 & 8.63 \\
Aspergillus spp. & 27 & 9.71 \\
Alternaria spp. & 39 & 14.02 \\
Cladosporium spp. & 48 & 17.26 \\
*Unidentified & 239 & - \\
\hline
\end{tabular}

* Non-sporulated monosporic colonies. fungi re-isolated from dead larvae at the end of each test confirmed the presence of the species used in the experiment (Table 4).

\subsection{Pathogenicity assay}

The results showed that treatments with fungi had a significant effect $(\mathrm{F} 23.64=\mathrm{df} 8 \mathrm{p}<0.01)$ on the mortality of larvae, ranging from 32 to $88 \%$, compared to $20 \%$ for the negative control (Figure 1). Isolates could be categorized into three groups: isolates that induced low mortality $(>40 \%)$, intermediate mortality (45-61\%), and highly mortality rates $(>80 \%)$. The treatment with the lowest performance was isolated CD34F1 (F. solani) with $32 \%$ mortality against $D$. fovealis. Isolates $\mathrm{G} 70$ (A. sydowii) and CD72E1 (A. terreus) induced mortality rates of 40 and $42 \%$, respectively; while for isolates OB96E2 (C. sphaerospermum) and G28 (C. cladosporioides), mortality rates were 38 and $48 \%$, respectively. Isolate G13, identified as D. endophytica, induced mortality of nearly $61 \%$ of larvae. The most virulent isolates obtained from mortality bioassays were $\mathrm{G} 42$ (P. lilacinus) and G41 (P. lilacinus) which induced mortality rates of 80 and $88 \%$, respectively.

\subsection{Estimation of the mean lethal concentration (LC50)}

The values of LC50 of two P. lilacinus isolates (G41 and G42) were similar (Table 5). The low slope $(0.524 \pm 0.081$ and $0.422 \pm 0.050)$ and $\chi^{2}$ values ( 0.444 and 0.880$)$, respectively indicate the Probit model was a good fit to the data. The effective lethal concentration was $3.6 \times 10^{7}$ conidia $/ \mathrm{mL}$ for $\mathrm{G} 41$ and $5.4 \times 10^{7}$ conidia $/ \mathrm{mL}$ for G42.

\section{Discussion}

The highest number of fungal endophytes isolates was obtained from strawberry leaves collected in area $\mathrm{A}$, which has been an organic farm for 12 years. Although area B is also characterized as an organic grower, the period of time converting from the conventional system to organic production was only three years and the biodiversity found was similar to those of conventional areas. The model of conventional agricultural is characterized by single crops, large dependence on chemical products, and high yields (Feiden et al., 2002). A considerable biodiversity is lost

Table 4. Molecular identification of species used in the mortality bioassay against $D$. fovealis.

\begin{tabular}{|c|c|c|c|}
\hline Species & Strain & GenBank Number & Gene \\
\hline Aspergillus terreus & CD72E1 & $\begin{array}{l}\text { KT427380 } \\
\text { KT427386 }\end{array}$ & $\begin{array}{c}\beta \text {-Tubulin } \\
\text { Calmodulin }\end{array}$ \\
\hline Aspergillus sydowwi & G70 & KT427381 & $\beta$-Tubulin \\
\hline Paecilomyces lilacinus & G41 & KT427382 & $\beta$-Tubulin \\
\hline Paecilomyces lilacinus & G42 & KT427383 & $\beta$-Tubulin \\
\hline Diaporthe endophytica & G13 & $\begin{array}{l}\text { KT427385 } \\
\text { KP2164961 }\end{array}$ & $\begin{array}{c}\text { ITS } \\
\text { Calmodulin }\end{array}$ \\
\hline Cladosporium sphaerospermum & OB96E2 & KP2164981 & ITS \\
\hline Cladosporium cladosporides & G28 & KP2164971 & ITS \\
\hline Fusarium solani & CD34F1 & KP2164951 & ITS \\
\hline
\end{tabular}


Table 5. Probit analysis of mortality and log-concentration of conidia using in the bioassay with two isolates against third instar larvae of D. fovealis.

\begin{tabular}{ccc}
\hline Treatment & G41 & G42 \\
\hline $\mathrm{N}^{\mathrm{o}}$ of larvae & 689 & 671 \\
${ }^{\mathrm{a}} \mathrm{LC}{ }_{50}$ & $3.6 \times 10^{7}$ & $5.4 \times 10^{7}$ \\
$\mathrm{Slope}(\mathrm{SE})$ & $0.524 \pm 0.081$ & $0.422 \pm 0.050$ \\
$95 \% \mathrm{FL}$ & $1.2 \times 10^{7}-8.4 \times 10^{7}$ & $1.3 \times 10^{7}-9.2 \times 10^{7}$ \\
$\chi^{2}(\mathrm{df}=4)$ & 0.444 & 0.880 \\
\hline
\end{tabular}

a LC50 values and their 95\% confidence levels are expressed in conidia per milliliter.

before being known, due to habitat fragmentation, excessive exploitation of natural resources, and contamination of soil and water, as well as of organisms in the agroecosystem (Altieri et al., 2005). Thus, information on the biodiversity is an important strategy in the ecological management of the populations inhabiting in the agroecosystem. Biodiversity creates a balance among species that, when it is restored, numerous and complex interactions are established among soil, plants, and animals (Altieri et al., 2005).

The genera Cladosporium, Trichoderma, Diaporthe, Phoma, and Alternaria isolated in this study can be used as antagonistic agents against phytopathogenic fungi. Cladosporium sp., Aspergillus sp., Nigrospora sp., Fusarium p., Trichoderma sp., Chaetomium sp., Alternaria sp., Paecilomyces sp., and Phyllostica are often isolated as endophytic fungi in several agricultural and native plant species (Azevedo, 1998; Rubini et al., 2005; Guo et al., 2008; Veja et al., 2008; Gazis and Chaverri, 2010; Kurose et al., 2012; Parsa et al., 2016). The genus Trichoderma sp. has been shown to induce resistance and enable plant defense (Rubini et al., 2005; Verma et al., 2007; Bailey et al., 2009; Kurose et al., 2012), while some species of the genera Fusarium and Paecilomyces can be used to control plant parasitic nematodes (Mendoza and Sikora, 2009). Furthermore, Aspergillus spp., Penicillium spp., and Chaetomium sp. are used in the industry for the production of secondary metabolites that exhibit antimicrobial and antifungal properties (Hanada et al., 2010; Li et al., 2011; Wang et al., 2012; Jouda et al., 2014).

C. cladosporioides and C. sphaerospermum were pathogenic for $D$. fovealis larvae. Endophytic species of the genera Cladosporium are used in the biocontrol of pests and diseases (Veja et al., 2008). Bahar et al. (2011) tested a strain of Cladosporium against larvae of Helicoverpa armigera (Hübner) (Lepidoptera: Noctuidae) and reported increased mortality rates of larvae. Similar results were obtained in this study, where $C$. cladosporioides and C. sphaerospermum were pathogenic to $D$. fovealis larvae.

Among the tested fungi, the isolates of $P$. lilacinus induced a high mortality rate of $D$. fovealis larvae. P. lilacinus is widely used in the biological control of diseases in plants cultivated under field conditions (Veja et al., 2008). Other studies performed with this species reported mortality in nymphs of Trialeurodes vaporariorum (Westwood)
(Hemiptera: Aleyrodidae) (Fiedler and Sosnowska, 2007) and showed a potential in the control of Nasonovia ribisnigri (Mosley, 1841) (Hemiptera, Aphididae) a pest of lettuce (Lactuca sativa L.) in Brazil (Zawadneak et., al. 2015b) and its applicability in the control of nematodes of the genus Meloidogyne sp. (Fiedler and Sosnowska, 2007).

In the present study, the isolate $D$. endophytica induced a mortality rate of $68 \%$ in $D$. fovealis. This endophytic species has not been reported as entomopathogenic in the literature. This is the first study to report this genus as a potential biological control agent of insects.

The isolates $\mathrm{G} 41$ and $\mathrm{G} 42$ had LC50 values considered good compared to those reported in the literature. Other studies have found significant results for isolates of this genus, as observed in our study. Hussein et al. (2013) treated third instar larvae of Spodoptera littoralis (Noctuide: Lepidoptera) with a new lineage of Paecilomyces sp (CCM 8367) in a suspension at a concentration of $5.0 \times 10^{7}$ conidia $/ \mathrm{mL}$ and reported a mortality rate above $90 \%$.

In conclusion, G41 and G42 isolates induced the highest mortality rates in D. fovealis larvae with the lowest LC50. Our findings showed the pathogenic and virulence potential of Paecilomyces lilacinus isolates as biological control agents against $D$. fovealis in laboratory as an alternative to currently employed traditional chemical insecticides. This is the first study on endophytic fungi isolated from strawberry tested against $D$. fovealis.

\section{Acknowledgements}

The authors thank Capes, CNPq and ProExt MEC SESU for financial support .

\section{References}

ABBOTT, W.S.A., 1925. A method of computing the effectiveness of an insecticide. Journal of Economic Entomology, vol. 18, no. 2, pp. 265-267. http://dx.doi.org/10.1093/jee/18.2.265a.

AKello, J.T., DUBOIS, T., GOLD, C.S., COYNE, D., NAKAVUMA, J. and PAPARU, P., 2007. Beauveria bassiana (Balsamo) Vuillemin as an endophyte in tissue culture banana (Musa spp.). Journal of Invertebrate Pathology, vol. 96, no. 1, pp. 34-42. PMid:17391694. http://dx.doi.org/10.1016/j.jip.2007.02.004.

ALTIERI, M., NICHOLLS, C. and FRITZ, M.A., 2005. Manage insects on your farm: a guide to ecological strategies. Beltsville: Sustainable Agriculture Network. 130 p.

ARNOLD, E.A. and LEWIS, L.C., 2005. Ecology and evolution of fungal endophytes and their roles against insects. In: F.E. VEGA and M. BLACKWELL, eds. Insect-fungal associations: ecology and evolution. New York: Oxford University Press, pp. 74-96.

ARNOLD, E.A., 2007. Understanding the diversity of foliar endophytic fungi: progress, challenges, and frontiers. Fungal Biology Reviews, vol. 21, no. 2-3, pp. 51-66. http://dx.doi. org/10.1016/j.fbr.2007.05.003.

ARNOLD, E.A. and LUTZONI, F., 2007. Diversity and host range of foliar fungal endophytes: are tropical leaves biodiversity hotspots? Ecology, vol. 88, no. 3, pp. 541-549. PMid: 17503580. http://dx.doi.org/10.1890/05-1459. 
ARNOLD, E.A., MEJÍA, C.L., KYLLO, D., ROJAS, E.I., MAYNARD, Z., ROBBINS, N. and HERRE, E.A., 2003. Fungal endophytes limit pathogen damage in a tropical tree. Proceedings of the National Academy of Sciences of the United States of America, vol. 100, no. 26, pp. 15649-15654. PMid:14671327. http://dx.doi.org/10.1073/pnas.2533483100.

AZEVEDO, J.L., 1998. Microrganismos endofíticos. In: I.S. MELOJ and L. AZEVEDO, eds. Ecologia Microbiana. Jaguariuna: Editora Embrapa, pp. 117-137.

BADALI, H., CARVALHO, V.O., VICENTE, V., ATTILIANGELIS, D., KWIATKOWSKI, I.B., VAN DEN ENDE, A.G. and HOOG, G.D., 2009. Cladophialophora saturnica sp. nov., a new opportunistic species of Chaetothyriales revealed using molecular data. Medical Mycology, vol. 47, no. 1, pp. 51-62. PMid:18720218. http://dx.doi.org/10.1080/13693780802291452.

BAHAR, M.H., BACKHOUSE, D., GREGG, P.C. and MENSAH, R., 2011. Efficacy of a Cladosporium sp. fungus against Helicoverpa armigera (Lepidoptera: Noctuidae), other insect pests and beneficial insects of cotton. Biocontrol Science and Technology, vol. 21, no. 12, pp. 1387-1397. http://dx.doi.or $\mathrm{g} / 10.1080 / 09583157.2011 .622036$.

BAILEY, B.A., STREM, M.D. and WOOD, D., 2009. Trichoderma species form endophytic associations within Theobroma cacao trichomes. Mycological Research, vol. 113, no. Pt 12, pp. 1365-1376. PMid:19765658. http://dx.doi.org/10.1016/j.mycres.2009.09.004.

BERNARDI, D., BOTTON, M., NAVA, D.E. and ZAWADNEAK, M.A.C., 2015.Guia para a identificação e monitoramento de pragas e seus inimigos naturais em morangueiro. Brasília: Embrapa. 46 p.

BONSIGNORE, C.P. and VACANTE, V., 2009. Emerging insects and pests in southern Italy. Protezione delle Colture, vol. 4, pp. 25-31.

CENTRE FOR AGRICULTURE AND BIOSCIENCE INTERNATIONAL - CABI, 2016 [viewed 4 June 2016]. Duponchelia fovealis (Southern European marshland pyralid) [online]. Available from: http://www.cabi.org/isc/datasheet/20168

EFIL, L., EFIL, F. and ATAY, E., 2014. New pest Duponchelia fovealis Zeller (Lepidoptera: Pyralidae) in peanut field. Journal of Applied Biological Sciences, vol. 5, pp. 65-67.

FEIDEN, A., DE ALMEIDA, D.L., VITOI, V. and ASSIS, R.L., 2002. Processo de conversão de sistemas de produção convencionais para sistemas de produção orgânicos. Cadernos de Ciência \& Tecnologia, vol. 19, no. 2, pp. 179-204.

FIEDLER, Ż. and SOSNOWSKA, D., 2007. Nematophagous fungus Paecilomyces lilacinus (Thom) Samson is also a biological agent for control of greenhouse insects and mite pests. BioControl, vol. 52, no. 4, pp. 547-558. http://dx.doi.org/10.1007/s10526006-9052-2.

FRANCO, C.M. and BAPTISTA, M., 2010. Duponchelia fovealis Zeller: nova praga em Portugal. Revista Frutas, Legumes e Flores, vol. 110, pp. 34-35.

GAZIS, R. and CHAVERRI, P., 2010. Diversity of fungal endophytes in leaves and stems of wild rubber trees (Hevea brasiliensis) in Peru. Fungal Ecology, vol. 3, no. 3, pp. 240-254. http://dx.doi.org/10.1016/j.funeco.2009.12.001.

GLASS, N.L. and DONALDSON, G.C., 1995. Development of primer sets designed for use with the PCR to amplify conserved genes from filamentous ascomycetes. Applied and Environmental Microbiology, vol. 61, no. 4, pp. 1323-1330. PMid:7747954.
GONZALEZ, F., TKACZUK, C., DINU, M.M., FIEDLER, Z., VIDAL, S., ZCHORI-FEIN, E. and MESSELINK, G.J., 2016. New opportunities for the integration of microorganisms into biological pest control systems in greenhouse crops. Journal of Pest Science, vol. 89, no. 2, pp. 295-311. PMid:27340390. http:// dx.doi.org/10.1007/s10340-016-0751-x.

GUO, B., WANG, Y., SUN, X. and TANG, K., 2008. Bioactive natural products from endophytes: a review. Applied Biochemistry and Microbiology, vol. 44, no. 2, pp. 153-142. PMid:18669256. http://dx.doi.org/10.1134/S0003683808020026.

HAJEK, A.E. and DELALIBERA, J.R.I., 2010. Fungal pathogens as classical biological control agents against arthropods. BioControl, vol. 55, no. 1, pp. 147-158. http://dx.doi.org/10.1007/ s10526-009-9253-6.

HANADA, R.E., POMELLA, A.W.V., COSTA, H.S., BEZERRA, J.L., LOGUERCIO, L.L. and PEREIRA, J.O., 2010. Endophytic fungal diversity in Theobroma cacao (cacao) and T. grandiflorum (cupuaçu) trees and their potential for growth promotion and biocontrol of black-pod disease. Fungal Biology, vol. 114, no. 11-12, pp. 901-910. PMid:21036333. http://dx.doi.org/10.1016/j. funbio.2010.08.006.

HUSSEIN, H.M., ZEMEK, R., HABUŠTOVÁ, S.O., PRENEROVÁ, E. and ADEL, M.M., 2013. Laboratory evaluation of a new strain CCM 8367 of Isaria fumosorosea (syn. Paecilomyces fumosoroseus) on Spodoptera littoralis (Boisd.). Archiv für Phytopathologie und Pflanzenschutz, vol. 46, no. 11, pp. 1307-1319. http://dx.doi.org/ 10.1080/03235408.2013.765677.

JONES, K.D., 1994. Aspects of the biology and biological control of the European corn borer in North Carolina. North Carolina: North Carolina State University, 254 p. Ph.D. Thesis.

JOUDA, J.B., KUSARI, S., LAMSHÖFT, M., TALONTSI, F.M., MELI, C.D., WANDJI, J. and SPITELLER, M., 2014. Penialidins A-C with strong antibacterial activities from Penicillium sp., an endophytic fungus harboring leaves of Garcinia nobilis. Fitoterapia, vol. 98, pp. 209-214. PMid:25128427. http://dx.doi. org/10.1016/j.fitote.2014.08.011.

KERN, M.E. and BLEVINS, K.S.,1999. Micologia médica: texto e atlas. 2nd ed. São Paulo: Premier. 256 p.

KUROSE, D., FURUYA, N., TSUCHIYA, K., TSUSHIMA, S. and EVANS, H.C., 2012. Endophytic fungi associated with Fallopiajaponica (Polygonaceae) in Japan and their interactions with Puccinia polygoni-amphibii var. tovariae, a candidate for classical biological control. Fungal Biology, vol. 116, no. 7, pp. 785-791. PMid:22749165. http://dx.doi.org/10.1016/j. funbio.2012.04.011.

LACEY, L.A., GRZYWACZ, D., SHAPIRO-ILAN, D.I., FRUTOS, R., BROWNBRIDGE, M. and GOETTEL, M.S., 2015. Insect pathogens as biological control agents: back to the future. Journal of Invertebrate Pathology, vol. 132, pp. 1-41. PMid:26225455. http://dx.doi.org/10.1016/j.jip.2015.07.009.

LECKIE, B.M., 2002. Effects of Beauveria bassiana mycelia and metabolites incorporated into synthetic diet and fed to larval Helicoverpa zea, and detection of endophytic Beauveria bassiana in tomato plants using PCR and ITS. Tennessee: The University of Tennessee, 96 p. Masters of Science Degree $</$ ths $>$.

LI, H.Q., LI, X.J., WANG, Y.L., ZHANG, Q., ZHANG, A.L., GAO, J.M. and ZHANG, X.C., 2011. Antifungal metabolites from Chaetomium globosum, an endophytic fungus in Ginkgo biloba. Biochemical Systematics and Ecology, vol. 39, no. 4-6, pp. 876-879. http://dx.doi.org/10.1016/j.bse.2011.06.019. 
MENDOZA, A.R. and SIKORA, R.A., 2009. Biological control of Radopholus similis in banana by combined application of the mutualistic endophyte Fusarium oxysporum strain 162, the egg pathogen Paecilomyces lilacinus strain 251 and the antagonistic bacteria Bacillus firmus. BioControl, vol. 54, no. 2, pp. 263-272. http://dx.doi.org/10.1007/s10526-008-9181-x.

MULÈ, G., SUSCA, A., STEA, G. and MORETTI, A., 2004. A species-specific PCR assay based on the calmodulin partial gene for identification of Fusarium verticillioides, F. proliferatum and F. subglutinans. European Journal of Plant Pathology, vol. 110, no. 5-6, pp. 495-502. http://dx.doi.org/10.1023/ B:EJPP.0000032389.84048.71.

OWNLEY, B.H., PEREIRA, R.M., KLINGEMAN, W.E., QUIGLEY, N.B., LECKIE, B.M., LARTEY, R.T. and CAESAR, A.J., 2004. Beauveria bassiana, a dual purpose biocontrol organism, with activity against insect pests and plant pathogens. Emerging Concepts in Plant Health Management, vol. 2, pp. 255-269.

PARSA, S., GARCÍA-LEMOS, A.M., CASTILLO, K., ORTIZ, V., LÓPEZ-LAVALLE, L.A.B., BRAUN, J. and VEGA, F.E., 2016. Fungal endophytes in germinated seeds of the common bean, Phaseolus vulgaris. Fungal Biology, vol. 120, no. 5, pp. 783-790. PMid:27109374. http://dx.doi.org/10.1016/j.funbio.2016.01.017.

POSADA, F. and VEGA, F.E., 2005. Establishment of the fungal entomopathogen Beauveria bassiana (Ascomycota: Hypocreales) as an endophyte in cocoa seedlings (Theobroma cacao). Mycologia, vol. 97, no. 6, pp. 1195-1200. PMid:16722213. http://dx.doi.org/ 10.1080/15572536.2006.11832729.

QUESADA-MORAGA, E., MARANHAO, E.A.A., VALVERDEGARCÍA, P. and SANTIAGO-ÁLVAREZ, C., 2006. Selection of Beauveria bassiana isolates for control of the whiteflies Bemisia tabaci and Trialeurodes vaporariorum on the basis of their virulence, thermal requirements, and toxicogenic activity. Biological Control, vol. 36, no. 3, pp. 274-287. http://dx.doi. org/10.1016/j.biocontrol.2005.09.022.

RUBINI, M.R., SILVA-RIBEIRO, R.T., POMELLA, A.W.V., MAKI, C.S., ARAÚJO, W.L., SANTOS, D.R. and AZEVEDO, J.L., 2005. Diversity of endophytic fungal community of cacao (Theobroma cacao L.) and biological control of Crinipellis perniciosa, causal agent of witches' wroom disease. International Journal of Biological Sciences, vol. 1, no. 1, pp. 24-33. PMid:15951847. http://dx.doi.org/10.7150/ijbs.1.24.

RUDGERS, J.A., HOLAH, J., ORR, S.P. and CLAY, K., 2007. Forest succession suppressed by an introduced plant-fungal symbiosis. Ecology, vol. 88, no. 1, pp. 18-25. PMid:17489448. http://dx.doi.org/10.1890/0012-9658(2007)88[18:FSSBAI]2.0.CO;2.

SCHULZ, B. and BOYLE, C., 2005. The endophytic continuum. Mycological Research, vol. 109, no. Pt 6, pp. 661-686. PMid:16080390. http://dx.doi.org/10.1017/S095375620500273X.

URRUTIA, M.I., ANGELES, H.B., ALIPPI, H.E., ROLLÁN, C. and LARRAN, S., 2002. Endophytic fungi in healthy soybean leaves. Investigación Agraria: Producción y Protección Vegetales, vol. 17, pp. 173-178.

VEGA, F.E., GOETTEL, M.S., BLACKWELL, M., CHANDLER, D., JACKSON, M.A., KELLER, S., KOIKE, M., MANIANIA, N.K., MONZON, A., OWNLEY, B.H., PELL, J.K., RANGEL, D.E.N. and ROY, H.E., 2009. Fungal entomopathogens: new insights on their ecology. Fungal Ecology, vol. 2, no. 4, pp. 149159. http://dx.doi.org/10.1016/j.funeco.2009.05.001.

VEJA, F.E., POSADA, F., AIME, M.C., PAVA-RIPOLL, M., INFANTE, F. and REHNER, S.A., 2008. Entomopathogenic fungal endophytes. Biological Control, vol. 46, no. 1, pp. 72-82. http://dx.doi.org/10.1016/j.biocontrol.2008.01.008.

VERMA, M., BRAR, S.K., TYAGI, R.D., SURAMPALLI, R.Y. and VALÉRO, J.R., 2007. Antagonistic fungi, Trichoderma spp.: Panoply of biological control. Biochemical Engineering Journal, vol. 37, no. 1, pp. 1-20. http://dx.doi.org/10.1016/j.bej.2007.05.012.

WANG, L.W., XU, B.G., WANG, J.Y., SU, Z.Z., LIN, F.C., ZHANG, C.L. and KUBICEK, C.P., 2012. Bioactive metabolites from Phoma species, an endophytic fungus from the Chinese medicinal plant Arisaema erubescens. Applied Microbiology and Biotechnology, vol. 93, no. 3, pp. 1231-1239. PMid:21814808. http://dx.doi.org/10.1007/s00253-011-3472-3.

WHITE, T.J., BRUNS, T., LEE, S. and TAYLOR, J., 1990. Amplification and direct sequencing of fungal ribosomal RNA genes for phylogenetics. In: M.A. INNIS, D.H. GELFAND, J.J. SHINSKY and T.J. WHITE, eds. PCR protocols: a guide to methods and applications. San Diego: Academic Press, pp. 315-322.

ZAWADNEAK, M.A.C., VIDAL, H.R. and SANTOS, B., 2015a. Lagarta-da-coroa, Duponchelia fovealis (Lepidoptera: Crambidae). In: E. VILELA and R.A. ZUCCHI, eds. Pragas introduzidas: insetos e ácaros. Piracicaba: ESALQ/ FEALQ, pp. 216-231.

ZAWADNEAK, M.A.C., PIMENTEL, I.C., ROBL, D., DALZOTO, P., VICENTE, V., SOSA-GÓMEZ, D.R., PORSANI, M. and CUQUEL, F.L., 2015b. Paecilomyces niveus Stolk \& Samson, 1971 (Ascomycota: Thermoascaceae) as a pathogen of Nasonovia ribisnigri (Mosley, 1841) (Hemiptera, Aphididae) in Brazil. Brazilian Journal of Biology $=$ Revista Brasileira de Biologia, vol. 75, no. 4, suppl. 1, pp. 158-162. PMid:26602345. http://dx.doi.org/10.1590/1519-6984.08014.

ZAWADNEAK, M.A.C., GONÇALVES, R.B., PIMENTEL, I.C., SCHUBER, J.M., SANTOS, B., POLTRONIERI, A.S. and SOLIS, M.A., 2016. First record of Duponchelia fovealis (Lepidoptera: Crambidae) in South America. Idesia, vol. 34, no. 3, pp. 1-5. http://dx.doi.org/10.4067/S0718-34292016000300011.

ZAWADNEAK, M.A.C., GONÇALVES, R.B., POLTRONIERI, A.S. SANTOS, B., BISCHOFF, A.M., BORBA, A.M., and PIMENTEL, I.C., 2017. Biological parameters of Duponchelia fovealis (Lepidoptera: Crambidae) reared in the laboratory on two diets. European Journal of Entomology, vol. 114, pp. 291-294. http://dx.doi.org/10.14411/eje.2017.035. 